\title{
Social Capital in Creating Food Security: Lessons Learned From Madukoro Village as a Food Independent Village (Dmp Program)
}

\author{
Fadlurrahman $^{1}$, Nike Mutiara Fauziah ${ }^{2}$ \\ \{Fadlurrahman@untidar.ac.id ${ }^{1}$, nikemutiara@iainpurwokerto.ac.id $\left.{ }^{2}\right\}$ \\ Tidar University ${ }^{1}$, UIN Prof. KH. Saifuddin Zuhri ${ }^{2}$
}

\begin{abstract}
Madukoro Village is a village that has successfully implemented the Food Independent Village (DMP) program in a short time, even this success has won it the food security award / Adhikarya Pangan Nusantara and the Arab Gulf Program for Development (AGFUND) Prize grant. The success of Madukoro Village is of course accompanied by the efforts of each of its residents, either individually or incorporated into village institutions, farmer groups, and other groups as well as the existence of a network of social relations (networks) between residents known as social capital. The study raised in this research is about social capital with the main objective of analyzing the management and role of social capital of the Madukoro Village community in creating food independence. The method used is a qualitative method with a case study approach. Data collection techniques in the form of FGD, in-depth interviews, observation, and documentation. The results showed that the people of Madukoro Village had long managed and used social capital to create food independence, namely since 1983. During the DMP program implementation process, social capital is managed successfully to achieve the objectives of the DMP program. A figure who has influenced the management of social capital and succeeded in embracing the community is Mr. Gun Haji as the executive leader of the DMP program. The condition of the social capital of the Madukuro Village community experienced extreme dynamics (weakened), after the DMP program ended. This is because Mr. Gun Haji declared retirement, and the community does not have a figure who is able to manage social capital to embrace society.
\end{abstract}

Keyword: Social Capital, Madukoro Village; Food Independent Village.

\section{Introduction}

Food security is an issue that continues to be discussed in the context of development and poverty alleviation in various forums for national and international meetings. In fact, food security has become an important issue in facing the changing world situation since 2000 because it greatly determines the economic, social and political stability of a country [1] [2]. On an international scale, institutions such as the Food and Agriculture Organization (FAO), Asia and the Pacific Economic Cooperation (APEC), the Association of Southeast Asia Nations (ASEAN), and the United Nations (UN) are increasingly discussing national security issues [3]. These institutions recognize that national resilience has a multidimensional effect on various aspects, particularly poverty and community welfare.

Based on the document of the Sustainable Development Goals (SDGs) indicator study conducted by BPS in 2014, food security was included in the SDGs goals of several international networks such as the High-Level Panel for Eminent Persons on Post-2015 Development Agenda 
(HLPEP) and the Open Working Group (OWG). Following the steps of the two international networks, BPS in its 2014 study proposed food security as one of the 17 SDGs goals that must be achieved by the government. Meanwhile, the Indonesian government through the Food Security Agency of the Ministry of Agriculture formulates a food security policy that focuses on: a. increasing the availability of diverse foods based on the potential of local resources; and b. Strengthen management of food insecurity to reduce the number of poor and hungry people.

One of the supporting programs for increasing community food security created by the Indonesian government is the Food Independent Village (DMP). DMP is an action program implemented by the Food Security Agency of the Ministry of Agriculture since 2006 with the aim of reducing food and nutrition insecurity through the use of rural resources, institutions and local wisdom so that people are expected to have the ability to realize food and nutrition security in order to live a sustainable life [4] [5]. The targets of the DMP program are poor and food insecure households that are developed in stages over four years with several approaches: community empowerment, institutional strengthening, development of food security systems and support for the development of village infrastructure [6].

Since the implementation of the DMP program in various regions of Indonesia from 2006 to the present, not all villages that were prepared as Independent Pangan Villages have succeeded in becoming Independent Pangan Villages. One of the villages that succeeded in establishing itself as a Food Independent Village was Madukoro Village, Kajoran District, Magelang Regency, Central Java Province in 2013. Before being categorized as an independent food village, Madukoro Village still had the status as a food independent replica village in 2011. A replica village independent food itself is a status received by the village to carry out various kinds of food security activities which in the future it is hoped that the status of the village can increase to become a Food Independent Village which means that it has experienced independence in fulfilling food for its people.

Over a period of approximately two years, Madukoro Village has succeeded in increasing food production, forming and expanding economic enterprises and reducing the number of poor families. With this success, Madukoro Village received an award for food security / Adhikarya Pangan Nusantara and delivered him as a recipient of the Arab Gulf Program for Development (AGFUND) Prize grant which is only given to two villages in Indonesia. The AGFUND funds are used as a pilot project to further strengthen and expand productive businesses through village financial institutions [6]

The village of Madukoro which is successful in establishing itself is certainly accompanied by the efforts of each of its citizens, either individually or who are members of village institutions, farmer groups and other groups as well as the existence of a network of social relations (networks) between residents which is called capital. social. [7] states that social capital is able to create food security in the form of collective solidarity in dealing with problems faced by society. In several studies, social capital has enormous benefits and has been empirically proven to be able to increase productivity, reduce poverty, prosper society, and make village development programs successful [8] [9][10][11].

For five years (2011-2016), the implementation of the DMP program in Madukoro Village was very successful. However, at the end of 2016, after the DMP program was completed, Madukoro Village did not progress significantly. Food and livestock products have decreased due to decreased community enthusiasm which has resulted in low activity in Madukoro Village. Even the euphoria of DMP is no longer visible, as can be seen from the inactivity of activities that support food self-sufficiency and security. This reality is allegedly due to the leadership factor in Madukoro Village. This problem has attracted the attention of researchers to examine from the perspective of social capital management, especially in relation to the DMP 
program in Madukoro Village with the aim of describing and analyzing social capital management during and after the DMP program ends, as well as analyzing leadership factors that can affect the social capital of the Madukoro Village community.

\subsection{Food Independent Village Program}

Food Independent Village Program (DMP) is an action program with a community empowerment approach implemented by the Food Security Agency of the Ministry of Agriculture since 2006 with the aim of reducing food and nutrition insecurity through the use of rural resources, institutions and local wisdom so that people are expected to have the ability to realize resilience. food and nutrition. in order to live a sustainable life [4] [5]. The DMP program itself runs for four years which is targeted to produce village independence in realizing food security. The targets of the DMP program are poor and food insecure households that are developed in stages over four years with several approaches: community empowerment, institutional strengthening, development of food security systems and support for village infrastructure development [6].

The implementation of the DMP program is designed through four stages which will culminate in the stage of village independence, including: (1) the preparatory stage, including the selection of food-insecure villages and the formation of groups of poor families, appointment of assistants and distribution of social assistance; (2) the stage of growth and development, coaching, counseling on the productive efforts of residents and the establishment of Village Financial Institutions (LKD), re-functioning of posyandu, improving the performance of food security systems from the aspects of availability, distribution, consumption and cross-sector coordination for the development of rural facilities and infrastructure; (3) the stage of development, institutional development and community business has begun to appear marked by an increase in the productive economy, an increase in DFS capital, and the development of a food security system; and (4) an independent stage marked by an increase in group dynamics and productive economic enterprises, a strong partnership network, the functioning of DFS as capital and the functioning of the Village Program Team (TPD) in coordinating cross-sector programs [4].

At the beginning of the implementation of the DMP program in villages that were selectively selected as locations for the implementation of the DMP program, the role of the central government was very dominant to form a coordination network between the central, regional, regional and village governments. Furthermore, if the village has developed into a core village in the food independence movement, the status of the village will change to become a pilot village which then moves and fosters the surrounding villages. When this happened, the role of the central government began to diminish and the role of local government became dominant. The success indicator of a village to become a core village can be seen from the functioning of various village institutions, especially LKD which will later function as a financial channel (savings and loans), the functioning of affinity groups, the distribution of social assistance funds for productive purposes. business, as well as increasing people's income, purchasing power and food security. 


\subsection{Social Capital and Its Role}

Social capital exists in every community that can be utilized by each of its members. Every community has the potential to create social capital consciously or unconsciously. The existence of social capital comes from local values and wisdom that accommodate common interests, customs or traditions, educational institutions, religious teachings, traditional institutions and others [12]. Dwiningrum [13] conceptualizes social capital as an actual and potential resource associated with ownership of a network that survives institutionalized and mutually respectful relationships. Furthermore, he stated that social capital means relationships that exist and are able to provide beneficial support to each member in the institutional network when needed.

In general, social capital can be defined as a relationship between individuals in a group that contains trust among its members. Clarifying this general understanding, the following researchers summarize some of the definitions of social capital put forward by various academics:

In general, social capital can be defined as a relationship between individuals in a group that contains trust among its members. Clarifying this general understanding, the following researchers summarize some of the definitions of social capital put forward by various academics:

Table 2. Various Definitions of Social Capital

\begin{tabular}{|c|c|c|}
\hline Ahli & Definisi Modal Sosial & Dimensi \\
\hline $\begin{array}{l}\text { Healy \& Hampshire } \\
(2002)\end{array}$ & $\begin{array}{l}\text { Social capital is the network, norms and } \\
\text { values that facilitate cooperation }\end{array}$ & $\begin{array}{l}\text { Network } \\
\text { Norms } \\
\text { Values }\end{array}$ \\
\hline Putnam (1993) & $\begin{array}{l}\text { The essence of social organizations, such } \\
\text { as trusts, social norms and networks that } \\
\text { enable the implementation of activities to } \\
\text { be more coordinated, and members of } \\
\text { the community can participate and } \\
\text { cooperate effectively and efficiently in } \\
\text { achieving common goals, and affect } \\
\text { productivity individually and in groups. }\end{array}$ & $\begin{array}{l}\text { Trust } \\
\text { Norms } \\
\text { Network } \\
\text { Reciprocity }\end{array}$ \\
\hline Coleman (1998) & $\begin{array}{l}\text { Social capital, namely trust, norms, } \\
\text { reciprocity and networks between } \\
\text { individuals in a group or organization }\end{array}$ & $\begin{array}{l}\text { Trust } \\
\text { Norms } \\
\text { Reciprocity } \\
\text { Network }\end{array}$ \\
\hline $\begin{array}{l}\text { Nahapiet \& Ghoshal } \\
\text { (1998) }\end{array}$ & $\begin{array}{l}\text { A number of tangible and potential } \\
\text { resources that are embedded, arise and } \\
\text { are derived from the network of } \\
\text { relationships of individuals or social } \\
\text { units }\end{array}$ & \\
\hline $\begin{array}{l}\text { Wisingera \& Black } \\
\text { (2006) }\end{array}$ & $\begin{array}{l}\text { A set of relationships between people or } \\
\text { groups that function to develop, access } \\
\text { and utilize existing resources }\end{array}$ & \\
\hline
\end{tabular}

Quoting some of the opinions of the experts above, the dimensions of social capital can be summed up into five dimensions, including trust, norms, reciprocity, network, and values. These five dimensions can be used as a measure of social capital in a group. Meanwhile, Woolcock (1998) provides three types of social capital, namely bonding, bridging and linking: (1) bonding, social capital which is binding refers to the relationship between individuals who are in primary 
groups or adjacent environments; (2) bridging, social capital that is bridging, namely the relationship that exists between different people, including people from different communities, cultures, and socio-economic backgrounds. The bridge that connects groups of bonding bonds [14][15] and (3) linking, social capital which is linking, enabling individuals to explore and manage resources, ideas, information and knowledge in a community.

Social capital has a vital role in achieving the goals of a group. Putnam in Aswasulasikin (2014) states why social capital is important in a group: first, social networks allow coordination and communication that fosters mutual trust among members. Second, trust has positive implications in people's lives, people who have high trust in one another in a social network will strengthen the norm by having to help each other. Third, the success achieved by social networks in the previous time will encourage success in the future. Empirically, Collier's (2002) research on the role of social capital concludes that social capital affects household poverty reduction through three types of externalities: (1) social capital facilitates the transmission of knowledge through social networks, both one-way and reciprocal interactions. (2) social capital can increase repeat transactions and reputation. (3) social capital reduces the problem of free riders by relying on norms and rules. In addition, social capital also facilitates poor households to receive benefits from membership in a social group [16].

\section{Methodology}

This study uses a qualitative method with a case study approach. The case study approach is a type of approach that examines a particular case. The type of single instrumental case study is the choice of researchers because it focuses on a particular problem or issue, namely social capital in the food security setting (DMP program). The research informants were selected using purposive sampling and snowball sampling techniques. Data collection was carried out using FGD techniques, in-depth interviews, observation and documentation. Then data analysis techniques through the process of data reduction, data presentation, and drawing conclusions.

\section{Finding and Discussion}

\subsection{Implementation of the Food Independent Village Program in Madukoro Village}

The Food Independent Village Program in Madukoro Village began in 2011, to be precise on March 11, 2011. Before being named the Independent Food Village (DMP), in 2011 Madukoro Village was appointed as a replica of the DMP. The status change from a DMP replica to a DMP took approximately three years, namely from 2011 - 2013.Before a village received the DMP status, the village was previously prepared in advance through four stages: the preparation stage, the growth stage, the development stage and the independence stage. with guidance by other villages that have DMP status.

Looking back at the early history that made Madukoro Village a DMP village, this started in 2008. In 2008, there was research in Madukoro Village conducted by several research teams from one of the universities in Indonesia which aimed to analyze the condition of the Madukoro Village community. who suffer from a lot of ispa to be precise in Madukoro two hamlets. The research resulted in the conclusion that many people in Madukoro Hamlet had ispa disease because the place where they lived was still adjacent to a goat pen. Departing from the results 
of this research, led to an initiative from the Head of Madukoro Dua Hamlet to hold hamlet meetings to find the right solution. Of course, the right solution for the residents of Madukoro Dua Hamlet is to move the cattle sheds far from where the community lives.

The problems faced by Madukoro Village, especially Madukoro Dua Hamlet, must be resolved quickly in the hope that there will be a decline in people suffering from ispa disease. The two heads of Madukoro Hamlet then formed a hamlet meeting involving the community to jointly find and decide on the most appropriate solution. The decisions and agreements that resulted in the deliberations were the creation of livestock villages. The livestock village is an integrated place (pen) as a storage for community livestock that is far from residential areas. Indeed, not all people agree and participate in the results of the existing agreements. Of the 25 breeders recorded in Madukoro Dua Hamlet in 2008, only 15 breeders played an active role and were willing to keep their livestock in the livestock village. However, this did not reduce the enthusiasm of the people of Madukoro Dua Hamlet to reduce the level of people with ispa disease. In the process, the livestock village can only accommodate five cattle pens. The capital for the development of the livestock village comes from community donations either in the form of goods or money voluntarily. What the people of Madukoro Dua Hamlet tried and did had "sweet" results for the community itself. There are fewer people with ispa, even livestock villages are growing and providing benefits to the community. Until finally, the livestock sector became one of the leading sectors in Madukoro Village which was also a factor in the implementation of the DMP program.

In addition, another indicator that makes Madukoro Village a place for implementing the DMP program is because Madukoro Village already has an embryo for the growth of activities that support food self-sufficiency, especially in the agriculture, fisheries and livestock sectors. Growth in these various sectors does not just happen, but there is a "trigger", namely to increase community income which then becomes the motivation for the people of Madukoro Village to progress and develop. The activities of the Madukoro Village community in supporting food self-sufficiency have actually been started since 1983 by using the concept of agroforestry, which is to convert the forest in the Madukoro Village area into community forest. Various kinds of plants and trees are planted on an area of 25 hectares with the hope that they can be enjoyed in the following years. The farmer group responsible for managing community forests is Reksobantolo.

The community forest in Madukoro Village has been successfully managed by the Reksobantolo group with the help and support of the community so that it provides very meaningful benefits to all Madukoro Village people. In addition, these community forests actually produce new springs that can be reused by the community to form and develop other sectors. Knowing this, a new group in the livestock and fisheries sector was born. The farmer group in the livestock sector is called Maju Lestari which is responsible for managing the cattle with a cage area of $210 \mathrm{~m} 2$, while the fisheries group named Ngudi Mina is responsible for managing 160 fish ponds covering an area of $6,446 \mathrm{~m} 2$. Of course, there are sustainable benefits generated from the management of these community forests. Starting from the aspirations and desire to make the village independent and prosper the community through community forest management, so that the people of Madukoro Village can enjoy the "sweet fruit" for what they have done in the past years.

Then from the side of the procedure for implementing the DMP program, another thing that determines the entry of the DMP program in Madukoro Village is because there are several villages in the same sub-district, namely Kajoran District which has the status of Independent Food Village (achieving food independence), including Wadas Village. (2010) and Wonogiri Village (2011). Villages that have achieved food independence are obliged to foster several 
villages by making these villages as independent food replica villages (DMP) based on the proximity of the area to food independent villages. Some of the villages fostered by Wadas Village are Bangsri Village, Madugondo Village, and Bumiayu Village. Meanwhile, Madukoro Village is under the guidance of Wonogiri Village along with Sambak Village, and Wuwuharjo Village as a food-independent replica village. It is true, procedurally the reason for implementing the DMP program in Madukoro Village is based on the proximity of the area to the village that has been declared a food independent village (Wonogiri Village), but behind that there are actually efforts of the people of Madukoro Village that cannot be forgotten. Some residents of Madukoro Village, especially those who are responsible for managing the livestock, agriculture and fisheries sectors, have imitated what Wonogiri Village did and tried to build relationships with various parties. Until finally, since the beginning of 2011, the status of a foodindependent replica village for Madukoro Village could change its status to become a foodindependent village in 2013. As information, Wonogiri Village itself has made preparations since 2006 before being declared a food independent village in 2011.

Seeing the success of the people of Madukoro Village who are slowly being able to independent themselves, in 2012 the government, especially the Kajoran District level, provided assistance of Rp. 25,000,000.00 as a stimulant fund for the goat / sheep livestock development program managed by the Maju Lestari affinity group. In the same year, 2012, Madukoro Village received a visit from the central government who was interested in seeing firsthand the implementation of the DMP program in Madukoro Village. Prior to the visit of the central government, Madukoro Village was first promoted by the district government to the provincial level and invited the provincial government to observe the condition of the DMP program in Madukoro Village. However, the provincial government considered the DMP program in Madukoro Village a failure. Even the provincial government always has another agenda when asked to visit, so the provincial government never visits Madukoro Village. Of course, this hampers the successful promotion of DMP in Madukoro Village. In the end, with the assistance of the district government, the success story of the DMP Desa Madukoro was directly conveyed to the central level. Procedurally, there are levels or stages that must be passed, starting from the sub-district, district, provincial, to the central level. However, because there is no support from the provincial government, initiatives must be taken. Upon this delivery, the central government agreed to visit and see firsthand the implementation of the DMP program in Madukoro Village. Knowing this too, the provincial government finally paid a visit to Madukoro Village because they had to accompany the central government.

After the visit of the central government to Madukoro Village, it turned out that the success story of the DMP program in Madukoro Village spread quickly. Madukoro Village has received various kinds of awards at the district, provincial and central levels. Even in 2013, Madukoro Village received an award directly from the President of the Republic of Indonesia at the Merdeka Palace, at that time it was held by Mr. Susilo Bambang Yodhoyono. In 2014, Madukoro Village was again visited by the provincial government. The visit was directly carried out by the Governor of Central Java Province, namely Mr. Ganjar Pranowo. Also in 2014, Madukoro Village was awarded the Arab Gulf Program for Development (Agfund) Prize with an assistance of Rp. 500,000,000.00 which was given to the Village Financial Institution (LKD) Naka mura. The assistance is intended for the development of DMPs to strengthen and expand productive businesses based on local resources and increase agricultural activities. The Agfund Prize award is only given to two villages in Indonesia (Munthuk Village, D.I. Yogyakarta and Madukoro Village, Central Java) for their success in creating food security. Before being named the winner of the Agfund Prize award, in 2013 the Maju sustainable affinity group engaged in the livestock sector received the Adhikarya Pangan Nusantara (APN) award as the first winner 
in the category of food security development actors. On the basis of the APN award, Madukoro Village is entitled to receive the Agfund Prize award funds.

Based on the narrative above, the entry of the Independent Food Village program to Madukoro Village was not due to geographical factors based on the proximity of the area to a village that has the status of a DMP village (Wonogiri Village). Indeed, territorial proximity is a procedure that must be determined administratively. But more than that, Madukoro Village already has an embryo to become a village worthy of being crowned a village with strong food security. Since 1983 the people of Madukoro Village began to move to become independent in the food sector. The implementation of the DMP program is thus not too difficult to implement because Madukoro Village already has sufficient capital (embryo). Of course, the existence of the DMP program in Madukoro Village in 2011 had a significant impact in creating food security. The government's desire to alleviate poverty through the DMP program is in line with the wishes of the Madukoro Village community.

\subsection{The existence of Madukoro Village Social Capital in the Food Independent Village Program}

The discourse on the use of social capital as a strategy to resolve various kinds of social problems, namely poverty, has long appeared at the 1995 United Nations (UN) conference in Copenhagen [10]. Even since the mid 1990s the concept of social capital has developed. This is also supported by various kinds of research on the effect of social capital on solving community problems. In several studies conducted by academics both quantitatively and qualitatively, social capital has an influence in addressing various kinds of social problems that are not limited to poverty. But more broadly, including problems of development, food security, food production, organizational effectiveness, empowerment, and so on [16] [9] [10].

Basically, social capital in each group already exists and exists in each group. Each group has social capital or has the potential to create social capital either consciously or unconsciously. Social capital is formed in the midst of society due to the harmonization of social relationships that occur between individuals (BPS, 2014). The existence of social capital comes from local values and wisdom that accommodate common interests, customs or traditions, religious teachings, traditional institutions, and others [12]. Social capital also exists among the people of Madukoro Village. The social capital in Madukoro Village already exists and continues to grow until the implementation of the Food Independent Village program. Since 1983, when the people of Madukoro Village committed to managing forests with the concept of agroforestry, social capital has been formed and started to be used to facilitate forest management activities, whether consciously or not. The existence of social capital for the Madukoro Village community continues to develop until it is institutionalized into a group, organization or formal institution that is useful for implementing the Food Independent Village program.

Dwiningrum [13] states that social capital is an actual and potential resource related to ownership of a network that survives institutionalized and mutually respectful relationships. According to what Dwiningrum [13] said, this also happened in Madukoro Village. This can be seen from the formation of groups which are actually a network and are formally institutionalized so that they have an important role in the implementation of the DMP program. These groups include the Naka Mura Village Financial Institution (LKD), the Reksobantolo (forestry) community forest farmer group, the Maju Lestari livestock farmer group (livestock) and the Ngudi Mina (fishery) farmer group. The formation of these groups was based on two conditions, first as a condition in implementing the DMP program because to reduce government assistance, a formal institution that had been formed in Madukoro Village was needed. Second, because the people of Madukoro Village themselves need new groups capable 
of managing other sectors. With the DMP program, the wishes of the residents can be realized, and even these groups are formed and have formal status.

In fact, many groups or organizations formed in Madukoro Village have different roles and functions. However, not all groups have a direct connection with the DMP program, only certain groups or institutions are responsible for implementing the DMP program, such as the Naka Mura Village Financial Institution (LKD), the Reksobantolo community forest farmer group, the Maju Lestari livestock farmer group, and the farmer Ngudi Mina. The formation of a community group or organization in Madukoro Village is part of the use of social capital, why is that? Because to form a group requires trust, norms, reciprocity, cooperation (network), and values that are believed by the community. Although on the one hand group formality is needed for the implementation of the DMP program, on the other hand it (the group) is a form of selfactualization of the Madukoro Village community to achieve food self-sufficiency through the use and management of their social capital.

The existence of social capital for the Madukoro Village community and its role in the DMP program will be discussed in the following dimensions. Mutual trust (trust) is one of the dimensions of social capital that is maintained and continuously built by the Madukoro Village community, especially between group / institution management, members, and the community. Mutual trust is used when group leaders or hamlet heads and village heads carry out an agenda by entrusting activities to members. A sense of reciprocity also arises when group members and the community believe in the leadership of group leaders, hamlet heads and village heads. Through mutual trust among the community, the values of togetherness and mutual cooperation are also fostered. For example, in the construction of livestock villages, people work hand in hand and together make stables. The enclosure is made without any assistance from the government, meaning that it is an initiative of the community itself. The community helps each other to provide capital for the construction of cages, either in the form of money or materials for making cages such as wood, nails, and so on. Mutual trust is the core of social strength in the community of Madukoro Village. Edy Setyawan as the executive secretary of the DMP program really admits that mutual trust is the initial capital in implementing the DMP program.

In terms of norms, the norms that apply in Madukoro Village function in maintaining good relations between communities. The Madukoro Village community believes that the prevailing norms can minimize conflicts that arise to the surface. Conflicts that arise are always resolved in a friendly manner by referring to religious norms and politeness. In implementing the DMP program, norms function as a set of social tools capable of binding the rights and obligations of the actors implementing the DMP program in particular, and all the people of Madukoro Village in general. From a legal standpoint, people have the right to economic prosperity. Of course, this right cannot be created without the accompanying obligations. Therefore, the community's obligation in the context of the DMP program is to participate in the implementation of the DMP program itself according to the job desk of each party. When the people of Madukoro Village are aware of their rights and obligations, the DMP program can automatically run according to the objectives set.

Then from the social network side, internally the social network (network) in Madukoro Village is illustrated by the continuous relationship between groups. Each group with an interest in the implementation of the DMP program has a good relationship both vertically and horizontally. The structure of the relationship between these groups is not clearly outlined, but in fact these groups need each other to make the DMP program a success. The Naka Mura Village Financial Institution, for example, has an important role in managing village finances and the finances of other groups in matters of savings and loans and capital. The other groups will of course always keep in touch with LKD Naka Mura in implementing activities that require 
a large enough budget, especially in the context of the DMP program. Then, the relationship between farmer groups that exists from the use of agricultural products, such as the results of the Reksobantolo farmer group which is used by the Maju Lestari farmer group is in the form of grass which is used as animal feed. Forest management carried out by the Reksobantolo farmer group has also resulted in a new spring in Madukoro Village which is beneficial for fisheries management managed by Ngudi Mina farmer group.

Externally, the social network between the Madukoro Village community can be seen from the relationship between the groups in Madukoro Village and groups or institutions outside Madukoro Village, such as government agencies or agencies and groups from other villages that are coaches of the DMP replica village. This relationship is built on the basis of the needs of the Madukoro Village community to introduce (promote) village potentials more broadly and to expedite the process of implementing the DMP program. The relationship that exists provides mutual benefits. When the government wishes to achieve the outputs and outcomes of the DMP program, Madukoro Village comes with the potential of the village. Likewise for Madukoro Village, when they wish to develop human resource capacity, develop the village, attract tourists, with the aim of community welfare, the government comes with various programs and assistance that are ready to be given to Madukoro Village. Seeing this relationship, the external social network built by Madukoro Village has a very important role in carrying out the DMP program so that in the end the welfare of the Madukoro Village community can be achieved.

Furthermore, a reciprocal attitude among the people of Madukoro Village is shown from the exchange of trust or kindness between them. When the hamlet or village head believes that the community is capable of implementing the DMP program, then the community believes that their leader is capable of being the leader of the DMP program. In several cases, the head of Madukoro Dua Hamlet (Mr. Mashud Gun Haji) was used as a leader who was highly trusted by the community in leading the DMP program. This is evident under the leadership of Mr. Gun Haji, Madukoro Village has succeeded in making a history of success and has become a prima donna for the government in the context of food security. Then an exchange of kindness is shown when the community volunteers to help each other in various DMP activities regardless of the rewards they get. There is only one desire of the people of Madukoro Village, which is to live in prosperity, be sufficient economically, and be strong in terms of food.

Of course, each group will try to maintain the social capital they have, because social capital is very useful in implementing the programs that have been scheduled. Even social capital contributes economically and socially.. In the case of implementing the DMP program, Madukoropun Village cannot be separated from the role of social capital. The people of Madukoro Village really pay attention to the norms and values that are carried, for example the value of togetherness. This value is so thick that it is able to encourage and move the community together (mutual cooperation) in achieving goals, for example making livestock villages. The desire of the community to be able to reduce poverty levels and improve welfare is the basis for maintaining existing social capital. When the people of Madukoro Village are committed and aspire to be independent, social capital will automatically be active in every activity carried out by the people of Madukoro Village. 


\subsection{The Role of Leaders in Managing Social Capital}

As stated in the previous sub-chapter, the social capital of the Madukoro Village community existed before the entry of the DMP program. However, this social capital is not 'automatically' perfect, meaning that it needs to be managed so that it can be utilized in the success of the goals and desires of society. Every Madukoro Village community is obliged to manage existing social capital by maintaining harmony, taking part and participating actively in every village activity. However, society needs an ideal figure who is able to embrace society and serve as a role model in managing social capital.

In some cases, village leaders or community leaders play an important role in managing social capital, because they are role models for their communities. So that what the community leaders do will greatly affect the existing social capital. One figure who has an important role in managing social capital in order to achieve the objectives of the DMP program is Mr. Mashud Gun Haji. Mr. Gun Haji is the head of Madukoro Dua Hamlet, Madukoro Village. In addition, he is also the coordinator of the DMP program, as well as the head of the Reksobantolo farmer group. Pak Gun is often considered a leader for the community in implementing the DMP program because he is able to bind all groups in Madukoro Village. Why is Pak Gun being "branded" like that, it is because the people believe in Pak Gun's leadership. Not only as the head of the hamlet, but as a figure capable of moving the community.

Pak Gun's success in managing and utilizing the existing social capital in Madukoro Village to create village independence is not "instant". As the DMP program coordinator, Pak Gun's performance is not limited to ordering the members, but also moving with the members. The story came from the informants, in implementing the DMP program Pak Gun was called a president who was strengthened by 10 working cabinets (Edi Setyawan, Iwan Jazimi, Surahmat, Nuroh Iman, Padang Setyawan, Lifmuh Wahyudin, Abdul Kholid Lutfi, Neli Mamuryati, Ismaya Khoifatul Maemunah, and Asriningsih). Pak Gun always encourages and motivates his members to make the DMP program a success. Every time a DMP activity proposal is submitted to the sub-district to the center, Pak Gun is always present and accompanies its members. What Pak Gun did, gave birth to loyalty and a close relationship between the chairman and its members. The phenomenon of the close relationship between Pak Gun and his members when viewed from the perspective of social capital, can be said that the visible dimensions of trust, norms, reciprocity, cooperation (network), and values are getting stronger. This further emphasizes that an ideal leader who is trusted by community members greatly affects the quality of existing social capital. When a leader believes in his members, reciprocity of trust will be created, when reciprocity has been created, cooperation and prevailing values will play and create benefits for the achievement of community goals.

\subsection{The Dynamics of Social Capital After the End of the Food Independent Village Program}

The implementation of the DMP program in Madukoro Village which lasted for five years (2011-2016) gave birth to stories, euphoria, and even recorded the history of the success of Madukoro Village in creating food independence and security. The potential of Madukoro Village in terms of natural resources, human resources, and even the potential for social capital is very supportive and plays an important role in the achievement of the DMP program. During the implementation of the DMP program, the social capital of Madukoro Village was of very good quality. This is proven by the strong harmonization of community relations during the DMP program until it has achieved significant success. 
After the DMP program ended in 2016, the success of Madukoro Village seemed to stop. Madukoro Village has not progressed significantly, even food and livestock yields have decreased significantly. This is because the community's enthusiasm for maintaining food security has begun to decline. What happened indicates that the social capital of the community is starting to weaken. Based on the reality in the field, the cause of the weakening of the quality of social capital in Madukoro Village is that the community, especially members of the DMP program, has lost their leader (Pak Gun). Mr. Gun stated that he was retiring as leader for health reasons. This situation is a problem for the members, because there is no replacement for Pak Gun who can embrace all members. This situation eventually gave birth to other problems that led to the loss of cohesiveness between members.

It should be acknowledged that the figure of a leader greatly influences the condition of social capital, and social capital also influences the achievement of goals, including in Madukoro Village itself. The lack of leadership regeneration is the main problem for Madukoro Village to return to achieving food security. In such conditions (a decrease in the morale of members due to the vacuum of leadership), the dynamics of social capital has experienced an extreme decline because there is no individual figure who manages social capital to be used in achieving goals.

Based on the above reality, it can be concluded that social capital in Madukoro Village is experiencing quite extreme dynamics. During the process of implementing the DMP program, the social capital of Madukoro Village has increased, but after the DMP program and the loss of a leader figure, the social capital of Madukoro Village began to weaken. It turns out that the figure of a leader greatly influences the condition and quality of social capital in society.

\section{Hope and Challenges of Madukoro Village in the Future in Realizing Food Security}

Reminiscing about the success story of Madukoro Village in creating food security gives new enthusiasm for the implementing members of the DMP program who were also informants in this study. The community wants to repeat the "golden era" that had happened in Madukoro Village. However, this desire is not easy to achieve because it is still constrained by the leadership vacuum. The biggest challenge faced is the problem of leader regeneration or regeneration. The Madukoro Village community needs a leader who is able to embrace and motivate the community to move forward regardless of the presence or absence of a program from the government. The social capital in Madukoro Village must be managed and utilized as well as possible, and that is a challenge for the next leader.

\section{Conclusion}

The implementation of the DMP program in Madukoro Village for five years was a success. The success in implementing the program is supported by the existence of social capital owned by the Madukoro Village community. The condition of the social capital of the Madukoro Village community experienced quite extreme dynamics both during the implementation of the DMP program and after the completion of the DMP program. The condition of social capital in Madukoro Village is strongly influenced by the leadership that becomes a role model for the community. When the figure of the leader retires from his job, immediately the spirit of the community decreases. This means that people's social capital begins to weaken 


\section{References}

[1] B. P. Statistik, Kajian Indikator Sustainable Development Goals (SDGs. Jakarta: Badan Pusat Statistik, 2014.

[2] S. R. Nurhemi, G. S. R. Soekro, and R. Suryani, "Pemetaan ketahanan pangan di Indonesia: Pendekatan TFP dan indeks ketahanan pangan.” Bank Indonesia, Jakarta, 2014.

[3] A. Suryana, "Menuju ketahanan pangan indonesia berkelanjutan 2025: tantangan dan penanganannya." 2014.

[4] V. Darwis, "Gerakan Kemandirian Pangan Melalui Program Desa Mandiri Pangan: Analisis Kinerja dan Kendala," Anal. kebijak. pertan., vol. 10, no. 2, p. 159, 2016, doi: 10.21082/akp.v10n2.2012.159-179.

[5] K. Hidayat and J. P. Nugraha, "PROGRAM AKSI DESA MANDIRI PANGAN:(Proses Pelaksanaan dan Dampaknya terhadap kondisi Sosial Ekonomi Rumahtangga Miskin di Desa Tamanasri, Kabupaten Pacitan," HABITAT, vol. 22, no. 2, pp. 84-97, 2013.

[6] B. K. Pangan, Laporan Tahunan Badan Ketahanan Pangan Tahun 2015. Jakarta: Kementrian Pertanian, 2016.

[7] R. Sinaga, "Peran Modal Sosial dalam Mendorong Sektor Pendidikan dan Pengembangan Wilayah di Kecamatan Garoga Kabupaten Tapanuli Utara,” 2012.

[8] T. Pranadji, "Penguatan Modal Sosial Untuk Pemberdayaan Masyarakat Pedesaan dalam Pengelolaan Agroekosistem Lahan Kering (Studi Kasus di Desa-desa (Hulu DAS) Ex Proyek Bangun Desa, Kabupaten Gunungkidul dan Ex Proyek Pertanian Lahan Kering.” Kabupaten Boyolali, 2016.

[9] S. Endarwati and E. S. Wahyuni, "Pengaruh Modal Sosial terhadap Ketahanan Pangan Rumahtangga Petani di Desa Ciaruteun Ilir Kecamatan Cibungbulang Kabupaten Bogor," J. penyul., vol. 10, no. 2, 2015, doi: 10.25015/penyuluhan.v10i2.9925.

[10] S. Yamin, "Pengentasan orang miskin di Indonesia: peran modal sosial yang terlupakan= Poverty alleviation in Indonesia: the missing link of social capital," Lib, 2015.

[11] R. A. R. S. Putra, B. Ariyadi, N. Kurniawati, and F. T. Haryadi, "Pengaruh Modal Sosial Terhadap Tingkat Kesejahteraan Rumah Tangga Peternak: Studi Kasus pada Kelompok Peternak Ayam Kampung Ngudi Mulyo, Gunungkidul,” Bul. Peternak., vol. 41, no. 3, pp. 349-354, 2017.

[12] S. Abdullah, "Potensi dan kekuatan modal sosial dalam suatu komunitas," SOCIUS J. Sosiol., vol. 12, no. 1, pp. 15-21, 2016.

[13] S. I. A. Dwiningrum, Modal Sosial dalam Pengembangan Pendidikan. Perspektif Teori dan Praktik, 2014.

[14] D. S. Brisson and C. L. Usher, "Bonding social capital in low-income neighborhoods," Fam. Relat., vol. 54, no. 5, pp. 644-653, 2005, doi: 10.1111/j.1741-3729.2005.00348.x.

[15] S. Zhang, S. G. Anderson, and M. Zhan, "The differentiated impact of bridging and bonding social capital on economic well-being: An individual level perspective," J. Soc. Soc. Welf., vol. 38, p. 119, 2011.

[16] A. Nasution, "Peranan modal sosial dalam pengurangan kemiskinan rumah tangga di perdesaan Indonesia,” J. Ekon. Kebijak. Publik, vol. 7, no. 2, pp. 171-183, 2017. 